\title{
INFLUENCE OF INCOME LEVEL ON CITIZEN PREPAREDNESS FOR RESPONSE TO NATURAL DISASTERS
}

\author{
Vladimir M. Cvetković \\ Academy of Criminalistic and Police Studies, Belgrade
}

\begin{abstract}
The aim of quantitative research is to examine the influence of income level on the citizen preparedness for response to a natural disaster caused by flood in the Republic of Serbia. Bearing in mind all local communities in Serbia where occurred or there is a high risk of flood occurrence, nineteen of 150 municipalities and 23 cities and the city of Belgrade were randomly chosen. In selected communities the research was performed in those areas that were most affected in relation to the water level or potential risk. The survey applied test strategy in households with the use of a multi-stage random sample. The research results indicated that the citizens who had income above RSD 90,000 at the household level, in a higher percentage took preventive measures, they know what floods are and know the safety procedures. On the other hand, citizens who have income below RSD 25,000 are not yet prepared, or intend to take certain measures in the next 6 months. The originality of the research stems from the fact of unexamined influence of income level on citizen preparedness. The research results can be used when creating strategies to improve the preparedness of citizens for response. The originality of the research is reflected in the fact that Serbia has not examined the influence of income level on preparedness of citizens to respond. The results can be used when creating a strategy to improve the level of citizen preparedness for response with regard to the level of citizen incomes.
\end{abstract}

Key Words: natural disasters, floods, citizens, income, preparedness for response, Serbia

\section{Introduction}

ncome realized by one household is an important factor when making decisions on

the adoption of certain measures of preparedness for response to natural disasters. The results of national research in the United States (FEMA, 2009), indicate that unemployed citizens $(47 \%)$ to a greater extent rely on the help of emergency-rescue services in relation to employees (31\%); employed people to a greater extent $(69 \%)$ believe that

\footnotetext{
*Vladimir M. Cvetković, Ph.D, vladimir.cvetkovic@kpa.edu.rs
} 
taking measures of preparedness, planning and acquisition of supplies will help them in natural disasters; also, they to a greater extent feel that improvement of preparedness will help them to deal with the consequences of natural disasters; Citizens with lower incomes to a greater extent rely on the competent authorities, they need help with evacuation or going to the shelter compared to households with higher incomes; unemployed citizens $(45 \%)$ to a greater extent rely on the help of other citizens compared to employees (34\%); citizens with lower incomes to a greater extent believe they could be affected by a natural disaster in the next 12 months; people with higher incomes to a greater extent believe that taking measures of preparedness, planning and acquisition of supplies will help them in natural disasters; furthermore, they are more confident in their abilities to cope with consequences of natural disaster; citizens with lower incomes to a greater extent, do nothing to raise the level of preparedness to a higher level; households with lower incomes to a greater extent were prepared in the past 6 months compared to households that earn more.

Various researches in the US suggest: people with higher incomes to a lesser extent, indicate that such measures are costly as a reason for not taking measures of preparedness and scored a higher level of preparedness to respond to disasters (CEG, 2006); furthermore, people with lower incomes (54\%) are less prepared to respond and attend training, compared to citizens with higher incomes (61\%). At the level of significance of $5 \%$ Baker (Baker, 2011) found that there is a significant statistical relationship between household income and the level of preparedness for response to a hurricane $\left(X^{2}=41.74\right.$, $d f=4, p=0.001<0.05)$. In a survey conducted in the United States, full-time employees showed a higher level of preparedness for response, especially emphasizing that their education and training conducted at work mean a lot for them (CEG, 2006).

In the literature, there is no generally accepted definition of preparedness for response to natural disasters (Cvetković, 2015abv; Ostojić, 2014; Vratuša-Žunjić, 2001). After all, it can easily get the impression that the determination of the content and scope of the term is somewhat marginalized (Cvetković, Gačić, \& Jakovljević, 2015). Preparedness as a concept in the theory of disasters includes activities undertaken before natural disasters in order to improve the response and recovery from the resulting consequences (Cvetković, 2015; Gillespie et al. 1993: 36). Tierney et al (Tierney, Lindell, \& Perry, 2002: 27) suggest that preparedness includes activities undertaken to strengthen the capabilities and opportunities of social groups to respond to situations caused by disasters. Thereby, they emphasize the inconsistency of preparedness with a clear focus on its two objectives: 1 . to help people to avoid the threat; 2 . to develop capacities and mechanisms with the aim of an effective response to disasters.

\section{Methodology and data}

Study design

Operationalization of the theoretical notion of preparedness to respond has given three dimensions that have been studied by identification of larger number of variables for each one (Figure 1). Perception of preparedness includes variables on preparedness 
at different levels; barriers for raising the level of preparedness; variables on the expectation on help from different categories of people and organizations; assessment of effectiveness of first responders to respond. Knowledge was examined through variables related to the level of knowledge; flood risk map; knowing where they are and how to use them, willingness to train, willingness for methods of education, way to obtain the information about floods. And the third dimensions, supplies relate to having oral/written plans, having supplies of food and water, a transistor radio, flashlight, hoe, shovel, hoe and spade, first aid kit, insurance.

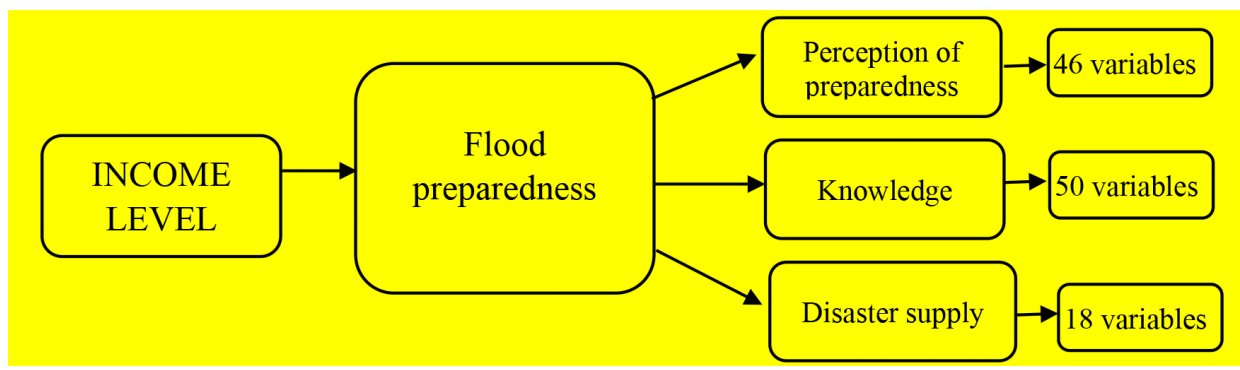

Figure 1 - Study design

\section{Sample}

The population consists of all adult residents of local communities in which there is a risk to occur flash flood or flood caused by dam failure. The sample size has been adjusted with the geographical (local communities from all regions of Serbia will be represented) and demographic size of the communities themselves. It was randomly selected sample of 19 of 150 municipalities and 23 towns and the city of Belgrade (Table 1 and Figure 2).

The research was undertaken in those areas that were most affected related to the amount of water or potential risk. In the survey, questioning strategy was applied to households with the use of a multi-stage random sample. In the first step, which refers to the primary causal units, parts of community in the research were selected. This process was accompanied by creation of map and determination of percentage share of each such segment in the total sample. In the second stage, streets or sections of streets were determined on the level of primary causal units. Each research core was determined as the path with specified start and end points of movement. In the next step, households in which the survey would be conducted were defined. The number of households is harmonized with population count of community. The final step referred to selection of respondents within households previously defined. The selection of respondents was conducted following the procedure of next birthday for adult members of household. The process of interviewing for each local authority was held three days in a week (including weekends) at different times of days. The study surveyed with 2,500 persons. 


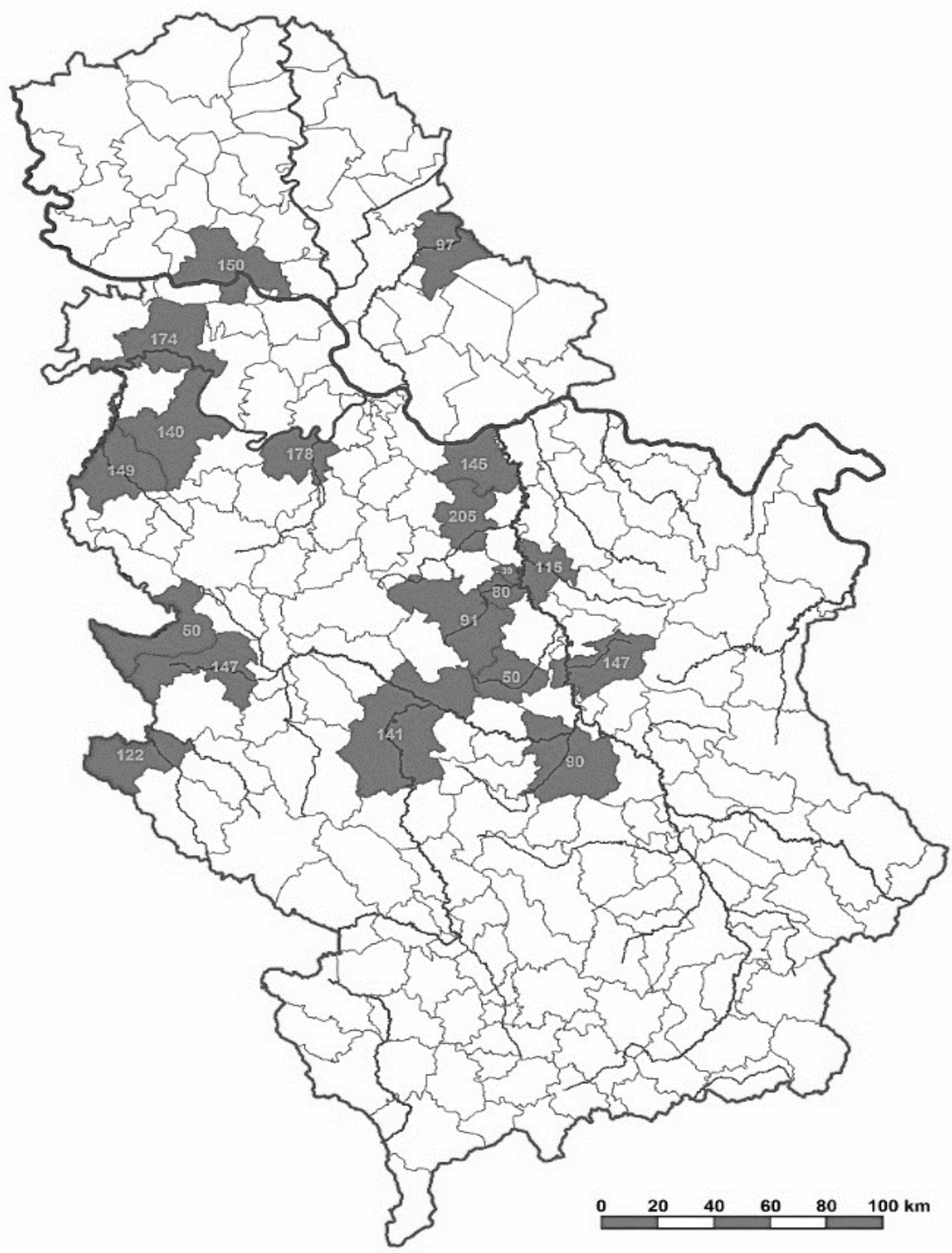

Figure 2 - Overview of the total number of respondents surveyed in local communities presented on the map of Serbia 
Table 1 - The number of the respondents in local communities in the study

\begin{tabular}{|c|c|c|c|c|c|c|}
\hline 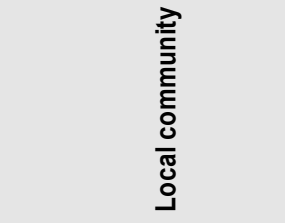 & 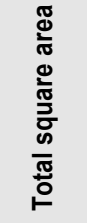 & 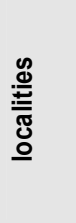 & $\begin{array}{l}\frac{\sigma}{0} \\
\frac{\pi}{\bar{\sigma}} \\
\frac{0}{0} \\
0\end{array}$ & 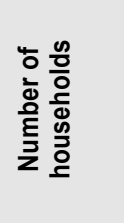 & 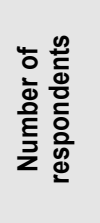 & 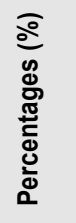 \\
\hline Obrenovac & 410 & 29 & 72682 & 7752 & 178 & 7.71 \\
\hline Šabac & 797 & 52 & 114548 & 19585 & 140 & 6.06 \\
\hline Kruševac & 854 & 101 & 131368 & 19342 & 90 & 3.90 \\
\hline Kregujevac & 835 & 5 & 179417 & 49969 & 91 & 3.94 \\
\hline Sremska Mitrovica & 762 & 26 & 78776 & 14213 & 174 & 7.53 \\
\hline Priboj & 553 & 33 & 26386 & 6199 & 122 & 5.28 \\
\hline Batočina & 136 & 11 & 11525 & 1678 & 80 & 3.46 \\
\hline Svilajnac & 336 & 22 & 22940 & 3141 & 115 & 4.98 \\
\hline Lapovo & 55 & 2 & 7650 & 2300 & 39 & 1.69 \\
\hline Paraćin & 542 & 35 & 53327 & 8565 & 147 & 6.36 \\
\hline Smederevska Palanka & 421 & 18 & 49185 & 8700 & 205 & 8.87 \\
\hline Sečanj - Jaša Tomić & 82 & 1 & 2373 & 1111 & 97 & 4.20 \\
\hline Loznica & 612 & 54 & 78136 & 6666 & 149 & 6.45 \\
\hline Bajina Bašta & 673 & 36 & 7432 & 3014 & 50 & 2.16 \\
\hline Smederevo & 484 & 28 & 107048 & 20948 & 145 & 6.28 \\
\hline Novi Sad & 699 & 16 & 346163 & 72513 & 150 & 6.49 \\
\hline Kraljevo & 1530 & 92 & 123724 & 19360 & 141 & 6.10 \\
\hline Rekovac & 336 & 32 & 10525 & 710 & 50 & 2.16 \\
\hline Užice & 667 & 41 & 76886 & 17836 & 147 & 6.36 \\
\hline Total - 19 & 10784 & 634 & 1500091 & 283602 & 2500 & 100 \\
\hline
\end{tabular}

Similar as in the entire population, the sample has more women $(50.2 \%)$ than men (49.8\%). In 2014, the average age of respondents was 39.95 (men 40.9 and women 38.61). Observing the educational structure of citizens who are included in the sample, it also can be noted that majority of population (41.3\%) has secondary/four years school. The smallest percentage of population has completed master $(2.9 \%)$ and doctoral studies $(0.4 \%)$. Marital status can be viewed from the aspect of legal marital status and factual marital status which also includes persons living in extramarital community. In the sample, married people account to $54.6 \%$, widow/widower $3 \%$, unmarried (single) $18.8 \%$, engaged $2.7 \%$ and in relationship $16.9 \%$. Table 2 gives a detailed overview of sample structure of surveyed citizens. 
Influence of Income Level on Citizen Preparedness for Response to Natural Disasters

Table 2 - Sample structure of interviewed citizens

\begin{tabular}{|c|c|c|c|}
\hline Variables & Categories & Frequency & Percentages (\%) \\
\hline \multirow{2}{*}{ Gender } & Male & 1244 & 49.8 \\
\hline & Female & 1256 & 50.2 \\
\hline \multirow{6}{*}{ Age } & $18-28$ & 711 & 28.4 \\
\hline & $28-38$ & 554 & 22.2 \\
\hline & $38-48$ & 521 & 20.8 \\
\hline & $48-58$ & 492 & 19.7 \\
\hline & $58-68$ & 169 & 6.8 \\
\hline & Over 68 & 53 & 2.2 \\
\hline \multirow{7}{*}{ Education } & Primary & 180 & 7.2 \\
\hline & Secondary/3 years & 520 & 20.8 \\
\hline & Secondary/4 years & 1032 & 41.3 \\
\hline & Higher & 245 & 9.8 \\
\hline & High & 439 & 17.6 \\
\hline & Master & 73 & 2.9 \\
\hline & Doctorate & 11 & 0.4 \\
\hline \multirow{6}{*}{ Marital status } & Single & 470 & 18.8 \\
\hline & In relationship & 423 & 16.9 \\
\hline & Engaged & 67 & 2.7 \\
\hline & Married & 1366 & 54.6 \\
\hline & Divorced & 99 & 4.0 \\
\hline & Widow / widower & 75 & 3.0 \\
\hline \multirow{4}{*}{$\begin{array}{l}\text { Distance between household and } \\
\text { river }(\mathrm{km})\end{array}$} & Up to $2 \mathrm{~km}$ & 1479 & 59.2 \\
\hline & From 2 to 5 & 744 & 29.8 \\
\hline & From 5 to 10 & 231 & 9.2 \\
\hline & Over 10 & 46 & 1.8 \\
\hline \multirow{4}{*}{ Number of household members } & Up to 2 & 63 & 2.5 \\
\hline & From 2 to 4 & 1223 & 48.9 \\
\hline & From 4 to 6 & 639 & 25.6 \\
\hline & Over 6 & 575 & 23.0 \\
\hline \multirow{2}{*}{ Employment status } & Yes & 1519 & 60.8 \\
\hline & No & 883 & 35.3 \\
\hline \multirow{5}{*}{ Size of apartment / house $\left(\mathrm{m}^{2}\right)$} & Up to 35 & 128 & 3.9 \\
\hline & $35-60$ & 237 & 7.2 \\
\hline & $60-80$ & 279 & 8.5 \\
\hline & $80-100$ & 126 & 3.9 \\
\hline & Over 100 & 45 & 1.4 \\
\hline \multirow{4}{*}{ Income level - montly } & Up to 25.000 RSD & 727 & 29.1 \\
\hline & Up to 50.000 RSD & 935 & 37.4 \\
\hline & U to 75.000 RSD & 475 & 19.0 \\
\hline & Over 90.0000 RSD & 191 & 7.6 \\
\hline
\end{tabular}




\section{Instrument}

For validity and reliablity studies of the data gathering instrument five steps were taken. In the first step, we determined some scales used for measuring the preparedness of citizens to respond to disasters in general or to specific natural disaster. The third step included the aforementioned operacionalization of preparedness for response and deciding on the three basic dimensions (perception of preparedness to respond, knowledge and supplies). In the fourth step, we defined variables for each dimension (perceptions of preparedness to respond - 46 variables; knowledge - 50 and supplies 18), then for each variable it was taken, adapted or specially designed question in instrument. The fifth and final step it was carried out preliminary (pilot) study in Batočina with the aim of checking constructed instrument (its internal compliance of the scale, i.e. degree of relatedness of items of which it is composed, and whether instructions, questions and values on scale are clear).

\section{Data analysis}

Statistical analysis of collected data was performed by IBM's software package SPSS. Chi-square test of independence $\left(X^{2}\right)$ was used for testing of the connection between gender and categorical variables on perception, knowledge and having supplies and plans for a natural disaster caused by flood. On that occasion additional assumptions were completed about minimum expected frequency in each cell, which amounted to five or more. Assessment of impact level was performed by phi coefficient representing the correlation coefficient ranging from 0 to 1 , where a higher number indicates a stronger relationship between the two variables. Koen criteria were used: from 0.10 for small, 0.30 for medium and 0.50 for large effect. For tables larger than 2 by 2, to assess the impact level it was used Cramer's $V$ coefficient which takes into account the number of degrees of freedom (Cohen, 1988). Accordingly, for R-1 or K-1 is equal to 1, we used the following criteria of impact size: small $=0.01$, medium $=0.30$ and large $=0.50$. To test the connection between gender and continuous dependent variables on the perception, knowledge and having supplies and plans for natural disasters caused by floods, it was selected independent samples t-test. Before proceeding to the implementation of the test, we examined general and specific assumptions for its implementation.

\section{Results and Discussion}

The results of Chi-square test of independence $\left(x^{2}\right)$ showed a statistically significant relationship between income level and the following variables: preventive measures $(p=0.000<0.05, v=0.080-$ small influence); financial resources $(p=0.000<0.05, v=0.143$ - small influence); engaged in the field $(p=0.004<0.05, v=0,083$ - small influence); river level rise $(p=0.000<0.05, v=0.115$ - small influence); preparedness level $(p=0.000<0.05, v=0.115$ - small influence). On the other hand, there was no 
statistically significant relationship with variables: engaged in shelters $(p=0.459>0.05)$, visiting flooded areas $(p=0.463>0.05)$, heavy rains $(p=0.111>0.05)$ and media reports $(p=0.429<0.05)$ (Table 3$)$. Based on results:

- In the highest percentage: citizens with household incomes over RSD 90,000 $(24.9 \%)$ have undertaken preventive measures, would give money to help victims affected by floods $(47.3 \%)$, water level rise makes them to think about preparedness $(42.9 \%)$, have recently started preparations $(11.1 \%)$ and they have prepared for at least 6 months (5.3\%); people with household incomes up to RSD 50,000 (20.7\%) would engage in providing assistance to victims in the field; people with household incomes up to RSD 25,000 are still not prepared, are intend to take measures in the next 6 months $(17.9 \%)$ are still not prepared, but will start preparing in next month $(13.3 \%)$;

- On the other hand, in the lowest percentage: citizens with household incomes up to RSD 25,000 (11.9\%) have undertaken preventive measures, would give money to help victims affected by floods (23.8\%), would engage in providing assistance to victims in the field $(13.5 \%)$, water level rise makes them to think about preparedness $(30.9 \%)$, they have prepared at least past 6 months $(2.1 \%)$, and do nothing to prepare for response to floods $(52.7 \%)$.

Table 3 - Results of the chi-square test of independence $(X 2)$ between income level and the variables on perception of preparedness to respond

\begin{tabular}{|l|c|c|c|c|}
\hline & value & df & Asymp. Sig. (2 - sided) & Cramers V \\
\hline Preventive measures & $\mathbf{2 7 , 1 1 4}$ & $\mathbf{6}$ & $\mathbf{0 0 0 ^ { * }}$ & $\mathbf{0 8 0}$ \\
\hline Funds & $\mathbf{4 4 , 8 3 1}$ & $\mathbf{3}$ & $\mathbf{0 0 0 ^ { * }}$ & $\mathbf{1 4 3}$ \\
\hline Engaged on the field & $\mathbf{1 5 , 4 6 1}$ & $\mathbf{4}$ & $\mathbf{0 0 4 ^ { * }}$ & $\mathbf{0 8 3}$ \\
\hline Engaged at reception centre & 3,627 & 4 &, 459 &, 040 \\
\hline Tour of flooded places & 2,567 & 3 &, 463 &, 035 \\
\hline Heavy rains & 6,015 & 3 &, 111 &, 053 \\
\hline Raising river level & $\mathbf{2 8 , 9 4 8}$ & $\mathbf{3}$ & $\mathbf{0 0 0 ^ { * }}$ &, $\mathbf{1 1 5}$ \\
\hline Media reports & 2,768 & 3 &, 429 &, 036 \\
\hline Preparedness level & $\mathbf{6 7 , 1 7 0}$ & $\mathbf{1 5}$ & $\mathbf{0 0 0 ^ { * }}$ & $\mathbf{1 0 2}$ \\
\hline
\end{tabular}

* Statistically significant correlation $(p \leq 0.05)$.

Using one-way analysis of variance (one-way ANOVA) it was studied the influence of income level of citizens on dependent continuous variables on the perception of preparedness to respond. Subjects were divided by income level into 4 groups (up to RSD 25,000, up to RSD 50,000, up to RSD 75,000 and over RSD 90,000). Using the homogeneity of variance test it was examined equality of variances in the results for each of the 4 groups. Bearing in mind the results Levene Statistic, the assumption of homogeneity of variance is not violated in the following variables: household preparedness; personal skills; ISS; religious communities; self-organized individuals; citizens from flooded areas; and efficiency of the police. For variable in which the assumption is violated, it was shown in table "Robust Tests of Equality of Means" and the results of two tests, Welsh and Brown - Forsythe tests resistant to a violation of the presumption of equality of variances. For research purposes, Welsh's results are used. 
Based on results, there is a statistically significant difference between the mean values of those groups in the following continuous dependent variables: household preparedness $(F=4.11, p=.006$, eta squared $=0.0052$ - small influence $)$; importance of taking preventive measures $(F=27.70, p=.000$, eta squared $=0.0348$ - small influence); ISS ( $F=4.43, p=.004$, eta squared $=0.0058$ - small influence); I have no time for that $(F=9.28, p=.000$, eta squared $=0.0121$ - small influence $)$; it is very expensive $(F=3.07, p=0.006$, eta squared $=0.0040-$ small influence); I have no support $(F=4.34, p=.005$, eta squared $=0,0057$ - small influence); $\mathrm{NHO}(F=5.73, p=.001$, eta squared $=0,0075$ - small influence); police $(F=4.91, p=.002$, eta squared $=0.0064$ - small influence); first responders $(F=6.46, p=.000$, eta squared $=0.0084$ - small influence); army $(F=9.14, p=0.000$, eta squared $=0.0118$ - small influence); help would not mean much $(F=6.49, p=0.000$, eta squared $=0.0088$ - small influence); preparedness of local communities $(F=4.34, p=.005$, eta squared $=0.0055$ - small influence); national preparedness $(F=4.00, p=0.008$, eta squared $=0.0049$ - small influence) personal abilities $(F=7.06, p=0.000$, eta squared $=0.0091$ - small influence); I can not prevent it $(F=2.92, p=0.033$, eta squared $=0.00393$ - small influence); household members ( $F=8.47, p=0.000$, eta squared $=0.00987$ - small influence); neighbors ( $F=9.64, p=0.000$, eta squared $=0.0114-$ small influence); $\mathrm{MHO}$ $(F=5.42, p=.001$, eta squared $=0,0074$ - small influence); religious communities $(F=8.62$, $p=0.000$, eta squared $=0.0114$ - small influence); emergency service $(F=3.59, p=.013$, eta squared $=0.0046-$ small influence); awareness $(F=11.963, p=.000$, eta squared $=0.0161-$ small influence); others helped $(F=3.93, p=0.008$, eta squared $=0.00513-$ small influence); duty of state authorities $(F=4.69, p=0.003$, eta squared $=0.0065$ - small influence); citizens of flooded areas $(F=3.52, p=.015$, eta squared $=0.0049$ - small influence); it is too expensive ( $F=13.81, p=0.000$, eta squared $=0.0179$ - small influence); police efficiency $(F=8.27, p=0.000$, eta squared $=0.0100-$ small influence); efficiency of first responders $(F=9.81, p=0.000$, eta squared $=0.0125$ - small influence); efficiency of emergency service $(F=11.45, p=0.000$, eta squared $=0.0160$ - small influence); army efficiency ( $F=7.58, p=0.000$, eta squared $=0.0097$ - small influence) (Table 4).

Subsequent comparisons using Turkey HSD show that the observed mean value:

- assessment of preparedness of households for response to floods statistically significantly $(p<0.05)$ and mutually differs among the citizens with household income above RSD 90,000 ( $M=3.25, S D=0.881)$ and citizens with incomes up to RSD 25,000 ( $M=2.98$, $S D=1.035)$. Citizens with incomes over RSD 90,000 scored a higher level of preparedness of households to respond to floods compared to citizens with income below RSD 25,000;

- assessment of national preparedness for response to floods statistically significantly $(p<0.05)$, and mutually differs among the citizens with household income below RSD $25,000(M=2.77, S D=1.225)$ and citizens with incomes below RSD 50,000 (M = 2.95, $\mathrm{SD}=1.056$ ). Citizens with incomes below RSD 50,000 scored a higher level of national preparedness for response to floods compared to citizens with income below RSD 25,000;

- assessment of preparedness of local community for response to floods statistically significantly $(p<0.05)$ and mutually differs among the citizens with household income below RSD 50,000 ( $M=3.06, S D=1.09)$ and citizens with incomes below RSD 25,000 ( $M=2.90$, $\mathrm{SD}=1.244)$. Citizens with incomes below RSD 50,000 scored a higher level of preparedness of local community for response to floods compared to citizens with income below RSD 25,000; 
- assessment of confidence in personal abilities to respond to floods statistically significantly $(p<0.05)$ and mutually differs among the citizens with household income over RSD 90,000 (M = 3.25, SD = 0.972) and citizens with incomes below RSD 25,000 $(\mathrm{M}=2.88, \mathrm{SD}=1.105)$. Citizens with incomes over RSD 90,000 scored a higher level of assessment of confidence in their own abilities to respond to floods compared to citizens with income below RSD 25,000;

- assessment of importance of taking preventive measures to reduce the material consequences of floods statistically significantly $(p<0.05)$ and mutually differs among the citizens with household income over RSD 90,000 (M = 3.67, SD =0.985) and citizens with incomes below RSD 25,000 (M = 3.10, SD = 1.202). Citizens with incomes over RSD 90,000 scored a higher level of assessment of importance of taking preventive measures to reduce the material consequences of floods compared to citizens with incomes below RSD 25,000;

- specifying the reason "I think first responders will help me, so I do not need such measures" for not taking preventive measures statistically significantly $(p<0.05)$, and mutually differs among the citizens with household income below RSD 25,000 ( $M=2.79$, $S D=1.346)$ and citizens with incomes below RSD 75,000 $(M=2.53, S D=1.309)$. Citizens with incomes below RSD 25.000 agree to a greater extent with specified reason compared to citizens with income below RSD 75,000;

- specifying the reason "I have no time for that" for not taking preventive measures statistically significantly $(p<0.05)$, and mutually differs among the citizens with household income below RSD 25,000 (M = $2.82 \mathrm{SD}=1,338)$ and citizens with income below RSD $75,000(M=2.43, S D=1.318)$. Citizens with incomes below RSD 25,000 agree to a greater extent with specified reason compared to citizens with income below RSD 75,000;

- specifying the reason "It is very expansive" for not taking preventive measures statistically significantly $(\mathrm{p}<0.05)$ and mutually differs among the citizens with household income below RSD 25,000 ( $M=2.83 \mathrm{SD}=1,340)$ and citizens with income below RSD 75,000 ( $M=2.60, S D=1.287$ ). Citizens with incomes below RSD 25,000 agree to a greater extent with specified reason compared to citizens with income below RSD 75,000;

- specifying the reason "I have no support from the local community" for not taking preventive measures statistically significantly $(p<0.05)$ and mutually differs among the citizens with household income below RSD 25,000 $(M=2.89, S D=1.344)$ and citizens with income below RSD 50,000 (M = 2.66, SD = 1.252). Citizens with incomes below RSD 25,000 agree to a greater extent with specified reason compared to citizens with income below RSD 50,000;

- specifying the reason "I can not prevent it" for not taking preventive measures statistically significantly $(p<0.05)$ and mutually differs among the citizens with household income below RSD 25,000 (M = 3.01, SD = 1.375) and citizens with income below RSD $50,000(M=2.82, S D=1.312)$. Citizens with incomes below RSD 25,000 agree to a greater extent with specified reason compared to citizens with income below RSD 75,000;

- expectations of help from household members in the first 72 hours after flood occurrence statistically significantly $(p<0.05)$ and mutually differs among the citizens with household income below RSD 25,000 (M = 4.16, SD = 1.273) and citizens with incomes over RSD 90,000 ( $M=4.52, S D=1.080)$. Citizens with incomes below RSD 25,000 expect to a greater extent help from household members compared to citizens with incomes over RSD 90,000; 
- expectations of help from neighbors in the first 72 hours after flood occurrence statistically significantly $(p<0.05)$ and mutually differs among the citizens with household income below RSD 25,000 (M = 3.48, SD = 1.341) and citizens with incomes over RSD $90,000(M=3.91, S D=1.062)$. Citizens with incomes below RSD 25,000 expect to a greater extent help from neighbors compared to citizens with incomes over RSD 90,000;

- expectations of help from non-governmental humanitarian organizations in the first 72 hours after flood occurrence statistically significantly $(p<0.05)$ and mutually differs among the citizens with household income below RSD 25,000 (M = 2.64, SD = 1.231 and citizens with incomes below RSD 75,000 ( $M=2.44$, SD = 1.181). Citizens with incomes below RSD 25,000 expect to a greater extent help from non-governmental humanitarian organizations compared to citizens with incomes over RSD 90,000;

- expectations of help from international humanitarian organizations in the first 72 hours after flood occurrence statistically significantly $(p<0.05)$ and mutually differs among the citizens with household income below RSD 25,000 ( $M=2.54$, SD $=1.220$ and citizens with incomes over RSD 90,000 ( $M=2.26, S D=1.122)$. Citizens with incomes below RSD 25,000 expect to a greater extent help from international humanitarian organizations compared to citizens with incomes over RSD 90,000;

- expectations of help from religious communities in the first 72 hours after flood occurrence statistically significantly $(p<0.05)$ and mutually differs among the citizens with household income below RSD 25,000 (M = 2.54, SD = 1.294) and citizens with household incomes below RSD 50,000 (M = 2.23, SD =1.152). Citizens with incomes below RSD 25,000 expect to a greater extent help from religious communities compared to citizens with incomes over RSD 90,000;

- expectations of help from the police in the first 72 hours after flood occurrence statistically significantly $(p<0.05)$ and mutually differs among the citizens with household income below RSD 25,000 (M = 3.23, SD = 1.328) and citizens with incomes below RSD $50,000$ ( $M=3.51, S D=1.247)$. Citizens with incomes below RSD 25.000 expect to a greater extent help from the police compared to citizens with incomes below RSD 70,000;

- expectations of help from first responders in the first 72 hours after flood occurrence statistically significantly $(p<0.05)$ and mutually differs among the citizens with household income below RSD 25,000 ( $M=3.51, S D=1.255)$ and citizens with incomes below RSD 75,000 ( $M=3.83, S D=1.203)$. Citizens with incomes below RSD 25,000 expect to a greater extent help from first responders compared to citizens with incomes over RSD 90,000;

- expectations of help from emergency medical services in the first 72 hours after flood occurrence statistically significantly $(p<0.05)$ and mutually differs among the citizens with household income below RSD 25,000 (M = 3.53, SD = 1.282) and citizens with incomes below RSD 75,000 (M = 3.55, SD = 1.186). Citizens with incomes below RSD 25,000 expect to a lesser extent help from emergency medical services compared to citizens with incomes below RSD 75,000;

- expectations of help from the army in the first 72 hours after flood occurrence statistically significantly $(p<0.05)$ and mutually differs among the citizens with household income below RSD 25,000 ( $M=3.41, \mathrm{SD}=1.365)$ and citizens with incomes below RSD $75,000(M=3.80, S D=1.309)$. Citizens with incomes below RSD 25,000 expect to a lesser extent help from the army compared to citizens with incomes below RSD 75,000; 
- assessment of awareness of potential flood risk statistically significantly $(p<0.05)$ and mutually differs among the citizens with household income below RSD 25,000 ( $M=2.66$, $S D=1.300)$ and citizens with incomes over RSD 90,000 $(M=3.28, S D=1.274)$. Citizens with incomes below RSD 25,000 to a lesser extent assess their awareness compared to citizens with incomes over RSD 90,000;

- specifying the reason "My help would not mean much" for potentially nonengagement in assisting victims affected by floods statistically significantly $(p<0.05)$ and mutually differs among the citizens with household income below RSD 25,000 ( $M=2.68$, $S D=1.316)$ and citizens with incomes over $R S D$ 90,000 $(M=2.27, S D=1.037)$. Citizens with incomes below RSD 25,000 specify to a greater extent this reason compared to citizens with incomes over RSD 90,000;

- specifying the reason "Others have already helped enough" for potentially nonengagement in assisting victims affected by floods statistically significantly $(p<0.05)$ and mutually differs among the citizens with household income below RSD 50,000 (M = 2.82, $S D=1.191)$ and citizens with incomes over RSD 90,000 $(M=2.53, S D=1.177)$. Citizens with incomes below RSD 50,000 specify to a greater extent this reason compared to citizens with incomes over RSD 90,000;

- specifying the reason "It is a duty of state authorities" for potentially nonengagement in assisting victims affected by floods statistically significantly $(p<0.05)$ and mutually differs among the citizens with household income below RSD 25,000 ( $M=3.05$, $S D=1.326)$ and citizens with incomes over RSD 90,000 $(M=2.69$, $S D=1.209)$. Citizens with incomes below RSD 25,000 specify to a greater extent this reason compared to citizens with incomes over RSD 90,000;

- specifying the reason "I expected people from flooded areas would be primarily engaged" for potentially non-engagement in assisting victims affected by floods statistically significantly $(p<0.05)$ and mutually differs among the citizens with household income below RSD 25,000 (M = 2.85, SD = 1.294) and citizens with incomes over RSD $90,000$ ( $M=2.85, S D=1.294)$. Citizens with incomes below RSD 25,000 specify to a greater extent this reason compared to citizens with incomes over RSD 90,000;

- specifying the reason "It is too expensive" for potentially non-engagement in assisting victims affected by floods statistically significantly $(p<0.05)$ and mutually differs among the citizens with household income below RSD 25,000 $(M=2.55, S D=1.303)$ and citizens with incomes over RSD 90,000 ( $M=2.02, S D=1.049)$. Citizens with incomes below RSD 25.000 specify to a greater extent this reason compared to citizens with incomes over RSD 90,000;

- assessment of efficiency of the police response during a natural disaster caused by flood statistically significantly $(p<0.05)$ and mutually differs among the citizens with household income below RSD 25,000 (M = 3.14, SD = 1.350) and citizens with incomes below RSD 75,000 (M = 3.49, SD = 1.115). Citizens with incomes below RSD 25,000 to a greater extent assess efficiency compared to citizens with incomes over RSD 90,000;

- assessment of efficiency of response of first responders during a natural disaster caused by flood statistically significantly $(p<0.05)$ and mutually differs among the citizens with household income below RSD 25,000 (M = 3.32, SD =1.330) and citizens with incomes below RSD 75,000 ( $M=3.71, S D=1.181$ ). Citizens with incomes below RSD 25,000 to a greater extent assess efficiency compared to citizens with incomes over RSD 90,000; 
- assessment of efficiency of response of emergency service during a natural disaster caused by flood statistically significantly $(p<0.05)$ and mutually differs among the citizens with household income below RSD 25,000 ( $\mathrm{M}=3.30, \mathrm{SD}=1.312)$ and citizens with incomes below RSD 75,000 (M = 3.61, SD = 1.133). Citizens with incomes below RSD 25,000 to a lesser extent assess efficiency compared to citizens with incomes over RSD 90,000;

- assessment of efficiency of the army response during a natural disaster caused by flood statistically significantly $(p<0.05)$ and mutually differs among the citizens with household income below RSD 25,000 (M = 3.57, SD = 1.408) and citizens with incomes below RSD 75,000 ( $M=3.91$, SD = 1.181). Citizens with incomes below RSD 25,000 to a lesser extent assess efficiency compared to citizens with incomes over RSD 90,000;

- assessment of efficiency of response of stuff for emergencies during a natural disaster caused by flood statistically significantly $(p<0.05)$ and mutually differs among the citizens with household income below RSD 25,000 (M = 3.13, SD =1.458) and citizens with incomes below RSD 75,000 ( $M=3.57, S D=1.272$ ). Citizens with incomes below RSD 25,000 to a lesser extent assess efficiency compared to citizens with incomes over RSD 90,000.

Table 4 - Results of one-way ANOVA of various groups of income levels and continuous dependent variables on the perception of preparedness for response

\begin{tabular}{|l|c|c|c|c|}
\hline \multicolumn{5}{|c|}{ Test of homogeneity of variance } \\
\hline & Levene Statistic & df1 & df2 & Sig. \\
\hline Individual preparedness & 3,567 & 3 & 2309 &, 014 \\
\hline Household preparedness & $\mathbf{1 , 8 6 9}$ & $\mathbf{3}$ & $\mathbf{2 3 1 7}$ &, $\mathbf{1 3 3 ^ { * }}$ \\
\hline Local community preparedness & 13,804 & 3 & 2302 &, 000 \\
\hline National preparedness & 5,317 & 3 & 2308 &, 001 \\
\hline Own capabilities & 5,427 & 3 & 2300 &, 001 \\
\hline Importance of protective measures & $\mathbf{2 , 2 6 7}$ & $\mathbf{3}$ & $\mathbf{2 3 0 3}$ &, $\mathbf{0 7 9}$ \\
\hline First responders & $\mathbf{1 , 0 2 5}$ & $\mathbf{3}$ & $\mathbf{2 2 7 8}$ &, $\mathbf{3 8 1 ^ { * }}$ \\
\hline I am not at risk & 2,953 & 3 & 2293 &, 031 \\
\hline I don't have time for this & $\mathbf{1 , 4 8 4}$ & $\mathbf{3}$ & $\mathbf{2 2 7 1}$ &, $\mathbf{2 1 7 ^ { * }}$ \\
\hline This is very expensive & $\mathbf{1 , 8 5 6}$ & $\mathbf{3}$ & $\mathbf{2 2 6 1}$ &, $\mathbf{1 3 5 ^ { * }}$ \\
\hline It will not affect the safety & 3,422 & 3 & 2266 &, 017 \\
\hline I am not capable & 3,750 & 3 & 2260 &, 011 \\
\hline I don't have support & $\mathbf{1 , 1 1 9}$ & $\mathbf{3}$ & $\mathbf{2 2 7 2}$ &, $\mathbf{3 4 0}$ \\
\hline I can't prevented & 3,673 & 3 & 2257 &, 012 \\
\hline Family members & 13,642 & 3 & 2283 &, 000 \\
\hline Neighbours & 12,547 & 3 & 2286 &, 000 \\
\hline $\begin{array}{l}\text { Non-governmental humanitarian } \\
\text { organizations }\end{array}$ & $\mathbf{2 , 1 8 3}$ & $\mathbf{3}$ & $\mathbf{2 2 7 1}$ &, $\mathbf{0 8 8}$ \\
\hline International humanitarian & 4,752 & 3 & 2270 &, 003 \\
\hline organizations & 5,890 & 3 & 2268 &, 001 \\
\hline Religious community & $\mathbf{4 6 2}$ & $\mathbf{3}$ & $\mathbf{2 2 8 1}$ &, $\mathbf{7 0 9}$ \\
\hline Police & $\mathbf{1 , 1 8 0}$ & $\mathbf{3}$ & $\mathbf{2 2 8 4}$ &, $\mathbf{3 1 6}$ \\
\hline Fire department & 3,360 & 3 & 2283 &, 018 \\
\hline Emergency aid & $\mathbf{1 , 2 7 4}$ & $\mathbf{3}$ & $\mathbf{2 2 8 5}$ &, $\mathbf{2 8 2}$ \\
\hline Army & $\mathbf{9 9 8 9}$ & $\mathbf{3}$ & $\mathbf{2 2 8 6}$ &, $\mathbf{3 9 7}$ \\
\hline Self-organized individuals & $\mathbf{5 , 9 3 4}$ & 3 & 2318 &, 000 \\
\hline Informed & & & & \\
\hline
\end{tabular}


Influence of Income Level on Citizen Preparedness for Response to Natural Disasters

\begin{tabular}{|l|c|c|c|c|}
\hline \multicolumn{5}{|c|}{ Test of homogeneity of variance } \\
\hline & Levene Statistic & df1 & df2 & Sig. \\
\hline Help would not make a deference & $\mathbf{2 , 2 8 6}$ & $\mathbf{3}$ & $\mathbf{2 1 7 8}$ &, $\mathbf{0 7 7}$ \\
\hline Others helped & 6,782 & 3 & 2173 &, 000 \\
\hline task of state bodies & 5,184 & 3 & 2155 &, 001 \\
\hline Citizens from flooded areas & 2,951 & 3 & 2165 &, 032 \\
\hline Lack of time & 6,671 & 3 & 2165 &, 000 \\
\hline It costs too much & 5,658 & 3 & 2271 &, 001 \\
\hline Efficiency of police & 3,389 & 3 & 2270 &, 017 \\
\hline Efficiency of fire department & 7,189 & 3 & 2269 &, 000 \\
\hline Efficiency of ambulance service & 14,136 & 3 & 2256 &, 000 \\
\hline & 6,888 & 3 & 2266 &, 000 \\
\hline
\end{tabular}

* assumption of the equality of variance is not violated - Sig. $>0.05$

\begin{tabular}{|c|c|c|c|c|c|c|}
\hline \multicolumn{7}{|c|}{ ANOVA } \\
\hline & & $\begin{array}{l}\text { Sum of } \\
\text { Squares }\end{array}$ & df & $\begin{array}{c}\text { Mean } \\
\text { Square }\end{array}$ & $\mathrm{F}$ & Sig. \\
\hline \multirow{3}{*}{ Individual preparedness } & Between Groups & 7,041 & 3 & 2,347 & 2,172 & ,089 \\
\hline & Within Groups & 2495,076 & 2309 & 1,081 & & \\
\hline & Total & 2502,117 & 2312 & & & \\
\hline \multirow{3}{*}{ Household preparedness } & Between Groups & 11,556 & 3 & 3,852 & 4,114 & ,006 \\
\hline & Within Groups & 2169,272 & 2317 & (936 & & \\
\hline & Total & 2180,828 & 2320 & & & \\
\hline \multirow{3}{*}{ Local community preparedness } & Between Groups & 15,829 & 3 & 5,276 & 4,313 & 005 \\
\hline & Within Groups & 2816,487 & 2302 & 1,223 & & \\
\hline & Total & 2832,316 & 2305 & & & \\
\hline \multirow{3}{*}{ National preparedness } & Between Groups & 15,424 & 3 & 5,141 & 3,857 &, 009 \\
\hline & Within Groups & 3076,589 & 2308 & 1,333 & & \\
\hline & Total & 3092,014 & 2311 & & & \\
\hline \multirow{3}{*}{ Own capabilities } & Between Groups & 22,185 & 3 & 7,395 & 7,056 &, 000 \\
\hline & Within Groups & 2410,544 & 2300 & 1,048 & & \\
\hline & Total & 2432,729 & 2303 & & & \\
\hline \multirow{3}{*}{$\begin{array}{l}\text { Importance of protective } \\
\text { measures }\end{array}$} & Between Groups & 102,164 & 3 & 34,055 & 27,706 &, 000 \\
\hline & Within Groups & 2830,747 & 2303 & 1,229 & & \\
\hline & Total & 2932,911 & 2306 & & & \\
\hline \multirow{3}{*}{ First responders } & Between Groups & 22,838 & 3 & 7,613 & 4,430 & ,004 \\
\hline & Within Groups & 3914,694 & 2278 & 1,718 & & \\
\hline & Total & 3937,532 & 2281 & & & \\
\hline \multirow{3}{*}{ I am not at risk } & Between Groups & 9,324 & 3 & 3,108 & 1,492 & ,215 \\
\hline & Within Groups & 4778,147 & 2293 & 2,084 & & \\
\hline & Total & 4787,471 & 2296 & & & \\
\hline \multirow{3}{*}{ I don't have time for this } & Between Groups & 49,198 & 3 & 16,399 & 9,281 & ,000 \\
\hline & Within Groups & 4012,966 & 2271 & 1,767 & & \\
\hline & Total & 4062,164 & 2274 & & & \\
\hline
\end{tabular}


VOJNO DELO, 4/2016

\begin{tabular}{|c|c|c|c|c|c|c|}
\hline \multicolumn{7}{|c|}{ ANOVA } \\
\hline & & $\begin{array}{l}\text { Sum of } \\
\text { Squares }\end{array}$ & df & $\begin{array}{l}\text { Mean } \\
\text { Square }\end{array}$ & $\mathrm{F}$ & Sig. \\
\hline \multirow{3}{*}{ This is very expensive } & Between Groups & 15,752 & 3 & 5,251 & 3,073 & ,027 \\
\hline & Within Groups & 3863,276 & 2261 & 1,709 & & \\
\hline & Total & 3879,029 & 2264 & & & \\
\hline \multirow{3}{*}{ It will not affect the safety } & Between Groups & 1,299 & 3 & ,433 & ,252 & 860 \\
\hline & Within Groups & 3894,572 & 2266 & 1,719 & & \\
\hline & Total & 3895,872 & 2269 & & & \\
\hline \multirow{3}{*}{ I am not capable } & Between Groups & 3,660 & 3 & 1,220 &, 705 &, 549 \\
\hline & Within Groups & 3911,545 & 2260 & 1,731 & & \\
\hline & Total & 3915,205 & 2263 & & & \\
\hline \multirow{3}{*}{ I don't have support } & Between Groups & 22,150 & 3 & 7,383 & 4,343 & ,005 \\
\hline & Within Groups & 3863,001 & 2272 & 1,700 & & \\
\hline & Total & 3885,151 & 2275 & & & \\
\hline \multirow{3}{*}{ I can't prevented } & Between Groups & 16,314 & 3 & 5,438 & 2,970 & ,031 \\
\hline & Within Groups & 4132,921 & 2257 & 1,831 & & \\
\hline & Total & 4149,235 & 2260 & & & \\
\hline \multirow{3}{*}{ Family members } & Between Groups & 34,153 & 3 & 11,384 & 7,590 &, 000 \\
\hline & Within Groups & 3424,435 & 2283 & 1,500 & & \\
\hline & Total & 3458,589 & 2286 & & & \\
\hline \multirow{3}{*}{ Neighbours } & Between Groups & 41,004 & 3 & 13,668 & 8,810 &, 000 \\
\hline & Within Groups & 3546,429 & 2286 & 1,551 & & \\
\hline & Total & 3587,433 & 2289 & & & \\
\hline \multirow{3}{*}{$\begin{array}{l}\text { Non-governmental humanitarian } \\
\text { organizations }\end{array}$} & Between Groups & 23,405 & 3 & 7,802 & 5,732 &, 001 \\
\hline & Within Groups & 3090,988 & 2271 & 1,361 & & \\
\hline & Total & 3114,393 & 2274 & & & \\
\hline \multirow{3}{*}{$\begin{array}{l}\text { International humanitarian } \\
\text { organizations }\end{array}$} & Between Groups & 22,186 & 3 & 7,395 & 5,654 & ,001 \\
\hline & Within Groups & 2968,900 & 2270 & 1,308 & & \\
\hline & Total & 2991,085 & 2273 & & & \\
\hline \multirow{3}{*}{ Religious community } & Between Groups & 38,648 & 3 & 12,883 & 8,753 &, 000 \\
\hline & Within Groups & 3337,824 & 2268 & 1,472 & & \\
\hline & Total & 3376,472 & 2271 & & & \\
\hline \multirow{3}{*}{ Police } & Between Groups & 25,084 & 3 & 8,361 & 4,915 & ,002 \\
\hline & Within Groups & 3880,474 & 2281 & 1,701 & & \\
\hline & Total & 3905,558 & 2284 & & & \\
\hline \multirow{3}{*}{ Fire department } & Between Groups & 28,895 & 3 & 9,632 & 6,469 &, 000 \\
\hline & Within Groups & 3400,552 & 2284 & 1,489 & & \\
\hline & Total & 3429,447 & 2287 & & & \\
\hline \multirow{3}{*}{ Emergency aid } & Between Groups & 15,831 & 3 & 5,277 & 3,521 & ,014 \\
\hline & Within Groups & 3421,882 & 2283 & 1,499 & & \\
\hline & Total & 3437,713 & 2286 & & & \\
\hline \multirow{3}{*}{ Army } & Between Groups & 48,537 & 3 & 16,179 & 9,140 &, 000 \\
\hline & Within Groups & 4044,966 & 2285 & 1,770 & & \\
\hline & Total & 4093,503 & 2288 & & & \\
\hline \multirow{3}{*}{ Self-organized individuals } & Between Groups & 12,029 & 3 & 4,010 & 2,207 & ,085 \\
\hline & Within Groups & 4153,973 & 2286 & 1,817 & & \\
\hline & Total & 4166,002 & 2289 & & & \\
\hline
\end{tabular}


Influence of Income Level on Citizen Preparedness for Response to Natural Disasters

\begin{tabular}{|c|c|c|c|c|c|c|}
\hline \multicolumn{7}{|c|}{ ANOVA } \\
\hline & & $\begin{array}{l}\text { Sum of } \\
\text { Squares }\end{array}$ & $\mathrm{df}$ & $\begin{array}{l}\text { Mean } \\
\text { Square }\end{array}$ & $F$ & Sig. \\
\hline \multirow{3}{*}{ Informed } & Between Groups & 58,676 & 3 & 19,559 & 12,719 &, 000 \\
\hline & Within Groups & 3564,401 & 2318 & 1,538 & & \\
\hline & Total & 3623,077 & 2321 & & & \\
\hline \multirow{3}{*}{$\begin{array}{l}\text { Help would not make a } \\
\text { deference }\end{array}$} & Between Groups & 30,032 & 3 & 10,011 & 6,493 & ,000 \\
\hline & Within Groups & 3359,446 & 2179 & 1,542 & & \\
\hline & Total & 3389,479 & 2182 & & & \\
\hline \multirow{3}{*}{ Others helped } & Between Groups & 16,509 & 3 & 5,503 & 3,750 & ,011 \\
\hline & Within Groups & 3195,769 & 2178 & 1,467 & & \\
\hline & Total & 3212,279 & 2181 & & & \\
\hline \multirow{3}{*}{ Task of state bodies } & Between Groups & 21,561 & 3 & 7,187 & 4,748 & ,003 \\
\hline & Within Groups & 3289,081 & 2173 & 1,514 & & \\
\hline & Total & 3310,642 & 2176 & & & \\
\hline \multirow{3}{*}{ Citizens from flooded areas } & Between Groups & 15,779 & 3 & 5,260 & 3,583 &, 013 \\
\hline & Within Groups & 3163,505 & 2155 & 1,468 & & \\
\hline & Total & 3179,284 & 2158 & & & \\
\hline \multirow{3}{*}{ Lack of time } & Between Groups & 12,768 & 3 & 4,256 & 2,566 & 053 \\
\hline & Within Groups & 3590,452 & 2165 & 1,658 & & \\
\hline & Total & 3603,221 & 2168 & & & \\
\hline \multirow{3}{*}{ It costs too much } & Between Groups & 55,764 & 3 & 18,588 & 13,192 &, 000 \\
\hline & Within Groups & 3050,499 & 2165 & 1,409 & & \\
\hline & Total & 3106,264 & 2168 & & & \\
\hline \multirow{3}{*}{ Efficiency of police } & Between Groups & 37,088 & 3 & 12,363 & 7,691 &, 000 \\
\hline & Within Groups & 3650,357 & 2271 & 1,607 & & \\
\hline & Total & 3687,444 & 2274 & & & \\
\hline \multirow{3}{*}{ Efficiency of fire department } & Between Groups & 47,167 & 3 & 15,722 & 9,653 &, 000 \\
\hline & Within Groups & 3697,157 & 2270 & 1,629 & & \\
\hline & Total & 3744,324 & 2273 & & & \\
\hline \multirow{3}{*}{ Efficiency of ambulance service } & Between Groups & 53,257 & 3 & 17,752 & 12,301 &, 000 \\
\hline & Within Groups & 3274,557 & 2269 & 1,443 & & \\
\hline & Total & 3327,813 & 2272 & & & \\
\hline \multirow{3}{*}{ Efficiency of army } & Between Groups & 38,471 & 3 & 12,824 & 7,418 &, 000 \\
\hline & Within Groups & 3900,106 & 2256 & 1,729 & & \\
\hline & Total & 3938,577 & 2259 & & & \\
\hline \multirow{3}{*}{$\begin{array}{l}\text { Headquarters for emergency } \\
\text { situations }\end{array}$} & Between Groups & 78,177 & 3 & 26,059 & 14,361 &, 000 \\
\hline & Within Groups & 4111,790 & 2266 & 1,815 & & \\
\hline & Total & 4189,967 & 2269 & & & \\
\hline
\end{tabular}

* There is a statistically significant difference between the mean values of dependent variables in 4 groups - Sig. $\leq 0.05$ 
VOJNO DELO, 4/2016

\begin{tabular}{|c|c|c|c|c|c|}
\hline \multicolumn{6}{|c|}{ Robust Testss of Equality of Means } \\
\hline & & Statistic $^{a}$ & df1 & df2 & Sig. \\
\hline \multirow{2}{*}{ Individual preparedness } & Welch & 2,396 & 3 & 745,222 &, 067 \\
\hline & Brown - Forsythe & 2,258 & 3 & 1455,683 &, 080 \\
\hline \multirow{2}{*}{$\begin{array}{l}\text { Local community } \\
\text { preparedness }\end{array}$} & Welch & 4,341 & 3 & 733,418 &, $005^{*}$ \\
\hline & Brown - Forsythe & 4,344 & 3 & 1298,864 &, $005^{*}$ \\
\hline \multirow{2}{*}{ National preparedness } & Welch & 4,001 & 3 & 736,481 &, $008^{*}$ \\
\hline & Brown - Forsythe & 3,906 & 3 & 1404,798 &, $009^{*}$ \\
\hline \multirow[b]{2}{*}{ Own capabilities } & Welch & 7,066 & 3 & 740,016 &, $000^{*}$ \\
\hline & Brown - Forsythe & 7,261 & 3 & 1427,077 & $000^{*}$ \\
\hline \multirow{2}{*}{ I am not at risk } & Welch & 1,621 & 3 & 742,270 & ,183 \\
\hline & Brown - Forsythe & 1,560 & 3 & 1475,494 & ,197 \\
\hline \multirow{2}{*}{ It will not affect the safety } & Welch &, 233 & 3 & 720,243 &, 873 \\
\hline & Brown - Forsythe & 245 & 3 & 1224,859 &, 865 \\
\hline \multirow[b]{2}{*}{ I am not capable } & Welch & 678 & 3 & 709,457 &, 566 \\
\hline & Brown - Forsythe & 680 & 3 & 1204,300 & .564 \\
\hline \multirow{2}{*}{ I can't prevented } & Welch & 2,924 & 3 & 707,637 &, $033^{*}$ \\
\hline & Brown - Forsythe & 3,004 & 3 & 1380,496 &, $029^{*}$ \\
\hline \multirow{2}{*}{ Family members } & Welch & 8,471 & 3 & 756,945 &, $000^{*}$ \\
\hline & Brown - Forsythe & 8,160 & 3 & 1574,018 &, $000^{*}$ \\
\hline \multirow{2}{*}{ Neighbours } & Welch & 9,643 & 3 & 755,078 &, $000^{*}$ \\
\hline & Brown - Forsythe & 9,380 & 3 & 1617,149 &, $000^{*}$ \\
\hline \multirow{2}{*}{$\begin{array}{l}\text { International humanitarian } \\
\text { organizations }\end{array}$} & Welch & 5,420 & 3 & 726,665 &, $001^{*}$ \\
\hline & Brown - Forsythe & 5,681 & 3 & 1349,122 &, $001^{*}$ \\
\hline \multirow{2}{*}{ Religious community } & Welch & 8,627 & 3 & 729,521 &, $000^{*}$ \\
\hline & Brown - Forsythe & 8,865 & 3 & 1418,947 &, $000^{*}$ \\
\hline \multirow{2}{*}{ Emergency aid } & Welch & 3,598 & 3 & 750,540 &, $013^{*}$ \\
\hline & Brown - Forsythe & 3,717 & 3 & 1531,103 &, $011^{*}$ \\
\hline \multirow{2}{*}{ Informed } & Welch & 11,963 & 3 & 728,585 &, $000^{*}$ \\
\hline & Brown - Forsythe & 12,513 & 3 & 1271,699 &, $000^{*}$ \\
\hline \multirow{2}{*}{ Others helped } & Welch & 3,936 & 3 & 696,994 &, $008^{*}$ \\
\hline & Brown - Forsythe & 3,815 & 3 & 1304,873 &, $010^{*}$ \\
\hline \multirow{2}{*}{ Task of state bodies } & Welch & 4,690 & 3 & 695,879 &, $003^{*}$ \\
\hline & Brown - Forsythe & 4,828 & 3 & 1282,037 &, $002^{*}$ \\
\hline \multirow{2}{*}{ Citizens from flooded areas } & Welch & 3,523 & 3 & 686,986 &, $015^{\star}$ \\
\hline & Brown - Forsythe & 3,521 & 3 & 1206,193 &, $015^{*}$ \\
\hline \multirow{2}{*}{ Lack of time } & Welch & 2,589 & 3 & 691,366 &, 052 \\
\hline & Brown - Forsythe & 2,553 & 3 & 1185,497 & 054 \\
\hline \multirow{2}{*}{ It costs too much } & Welch & 13,812 & 3 & 713,514 &, $000^{*}$ \\
\hline & Brown - Forsythe & 14,185 & 3 & 1483,185 &, $000^{*}$ \\
\hline \multirow{2}{*}{ Efficiency of police } & Welch & 8,272 & 3 & 732,284 &, $000^{*}$ \\
\hline & Brown - Forsythe & 8,129 & 3 & 1398,771 &, $000^{*}$ \\
\hline \multirow{2}{*}{ Efficiency of fire department } & Welch & 9,861 & 3 & 722,676 &, $000^{*}$ \\
\hline & Brown - Forsythe & 9,825 & 3 & 1296,389 &, $000^{*}$ \\
\hline Efficiency of ambulance & Welch & 11,454 & 3 & 712,352 &, $000^{*}$ \\
\hline service & Brown - Forsythe & 12,095 & 3 & 1224,370 &, $000^{*}$ \\
\hline Efficioncy of army & Welch & 7,583 & 3 & 722,656 &, $000^{*}$ \\
\hline Efticiency of army & Brown - Forsythe & 7,598 & 3 & 1301,998 &, $000^{*}$ \\
\hline
\end{tabular}

* There is a statistically significant difference between the mean values of dependent variables in 4 groups - Sig. $\leq 0.05$ 


\section{Relationship between income level and knowledge about floods}

The results of Chi-square test of independence $\left(x^{2}\right)$ showed a statistically significant relationship between income level and the following variables on knowledge: familiarity with safety procedures ( $p=0.006<0.05, v=0.065$ - small influence); evacuation $(p=0.000<$ $0.05, v=0.106-$ small influence); education at school $(p=0.000<0.05, v=0.084-$ small influence); education at work $(p=0.000<0.05, v=0.103-$ small influence); elders, disabled ( $p=0.023<0.05, v=0,058$ - small influence); consent to evacuation ( $p=0.000<$ $0.05, v=0.098$ - small influence); help - elders, disabled $(p=0.009<0.05, v=0.098-$ small influence); neighbors - individually $(p=0.000<0.05, v=0.109-$ small influence); flood risk map ( $p=0.000<0.05, v=0,102-$ small influence); official warning $(p=0.000<$ $0.05, v=0,101$ - small influence); potential infections $(p=0.050<0.05, v=0,059$ - small influence); water valve $(p=0.003<0.05, v=0.073$ - small influence); electricity switch $(p=0.013<0.05, v=0,061$ - small influence); information from neighbors $(p=0.003<$ $0.05, v=0.080$ - small influence); information from a friend $(p=0.000<0.05, v=0.111-$ small influence); information from relatives $(p=0.009<0.05, v=0.073$ - small influence); information at school $(p=0.022<0.05, v=0.066-$ small influence); information in collage $(p=0.000<0.05, v=0.162-$ small influence); information on the radio $(p=0.015<0.05$, $v=0.069$ - small influence); information from the press $(p=0.003<0.05, v=0.080-$ small influence); information over the Internet $(p=0.000<0.05, v=0.138-$ small influence); trained ( $p=0.007<0.05, v=0.079$ - small influence); desire for training $(p=0.000<0.05, v=0.119-$ small influence); education. on television $(p=0.000<0.05$, $v=0.138$ - small influence); education on the radio $(p=0.007<0.05, v=0.079-$ small influence); education through the Internet $(p=0.000<0.05, v=0.122$ - small influence); education through lectures ( $p=0.000<0.05, v=0,145-$ small influence). On the other hand, there was no statistically significant relationship with variables: education within the family $(p=0.073>0.05)$, gas valve $(p=0.274>0.05)$, handling water valve $(p=0.602>$ $0.05)$, handling gas valve $(p=0.274>0.05)$, handling electricity switch $(p=0.132>0.05)$, information from household members $(p=0.192>0.05)$, information through an informal system $(p=0.321>0.05)$, information at work $(p=0.079>0.05)$, information in a religious community $(p=0.471>0.05)$, information on television $(p=0.134>0.05)$, education through video - games $(p=0.267>0.05)$, informal system $(p=0.878>0.05)$ (Table 5).

The results indicate that in the highest percentage:

- Citizens with household incomes over RSD 90,000 know what floods are (88.4\%) and know safety procedures $(30.9 \%)$, say that somebody at school told them about floods $(29.2 \%)$, they know what help is needed by elders, disabled and infants during floods $(94.3 \%)$, would evacuated themselves to a friend's place during floods $(47.6 \%)$; say that their neighbors can self-rescue in the event of floods (54.9\%), they know what to do after an official warning about the approach of the flood wave $(34.8 \%)$ state that they are familiar with viruses and infections that accompany period after the floods $(54.9 \%)$, they know where the water valve is $(84.6 \%)$, electricity switch $(85.7 \%)$; they received information on floods over the Internet $(37.4 \%)$; they have been given training in the field of natural disasters (8.5\%); they would like to be educated about natural 
disasters caused by floods over the radio $(15.6 \%)$, the Internet $(38.5 \%)$, non-formal education (40.5\%);

- Citizens with household incomes below RSD 75,000 (41.8\%) stated that someone at work talked about the floods, they know where live elders, disabled and infants $(43.7 \%)$ would be evacuated during floods $(94,3 \%)$, they received information about floods from relatives $(14.2 \%)$, at school $(18.2 \%)$, in college $(14.7 \%)$, on the radio $(17.9 \%)$ and in the press $(36.9 \%)$;

- Citizens with household incomes below RSD 50,000 would be evacuated to the upper floors of the house during the floods (40.6\%); would be evacuated to the rented apartments during the floods (4.5\%); point out that they are familiar with flood risk map in the local community $(11.1 \%)$; point out that they got information on floods from neighbors (18.1\%), friends $(14.2 \%)$;

- Citizens with household incomes below RSD 25,000 would be evacuated to neighbors' places during floods (13\%), would be evacuated to shelters during the floods $(17.4 \%)$; point out that they would like to undergo some training in the field of natural disasters $(31.3 \%)$ and state that they would like to be educated about natural disasters caused by floods on television (67.2\%);

On the other hand, in the smallest percentage:

- Citizens with household incomes over RSD 90,000 would be evacuated to neighbors' places during floods (31\%) would be evacuated to rented apartments $(0.5 \%)$; suggest they would evacuated themselves during floods $(84.5 \%)$; point out that they know where the water valve is $(76.5 \%)$; point out they received information on floods from neighbors $(8.7 \%)$; point out that they would like to be educated about natural disasters caused by floods on television (51.4\%); point out that they would like to be educated about natural disasters caused by floods over the radio $(9.5 \%)$, the Internet (20.3\%), non-formal education (23.6\%);

- Citizens with household incomes below RSD 75,000 know what floods are (78.7\%) and know safety procedures $(22.4 \%)$; would be evacuated to the upper floors of the house during the floods (36.1\%); would be evacuated to shelters during floods $(10.3 \%)$; point out that their neighbors can self-rescue in the event of floods $(30.5 \%)$; claim that they know what to do after an official warning about the approach of the flood wave (18.3\%); point out that they know where electricity switch is $(77.6 \%)$;

- Citizens with household incomes below RSD 50,000 point out that somebody at school talked them about floods (25.1\%); point out that they are familiar with viruses and infections that accompany period after floods (42.9\%); point out that they have been given training in the field of natural disasters (4.1\%);

- Citizens with household incomes below RSD 25,000 would be evacuated to a friend's place during floods $(29.9 \%)$ stated that someone at work talked them about the floods $(28.8 \%)$, they know where live elders, disabled and infants $(41.9 \%)$, they know what help is needed by elders, disabled and infants during floods $(51.8 \%)$ they are familiar with flood risk map in the local community (17.2\%) state they got information on floods from neighbors $(6.2 \%)$, relatives $(12.1 \%)$, in collage $(1.9 \%)$, on the radio $(12.3 \%)$, in newspapers $(26.8 \%)$ over the Internet $(19.6 \%)$. 
Influence of Income Level on Citizen Preparedness for Response to Natural Disasters

Table 5 - Results of Chi-square test of independence (X2) of income level and knowledge as an element of preparedness for response

\begin{tabular}{|c|c|c|c|c|}
\hline & value & df & Asymp. Sig. (2 - sided) & Cramer's v \\
\hline Knowledge of the flood & 13,808 & 6 & ,032* &, 055 \\
\hline Knowledge of safety procedures & 18,257 & 6 &, $006^{*}$ & 065 \\
\hline Evacuation & 71,241 & 12 &, $000^{*}$ & ,106 \\
\hline Education at school & 31,290 & 8 &, $000^{*}$ &, 084 \\
\hline Education in family & 14,358 & 8 &, 073 &, 057 \\
\hline Education at work & 45,532 & 8 &, $000^{*}$ & ,103 \\
\hline Seniors, handicapped and infants & 14,663 & 6 &, $023^{*}$ & ,058 \\
\hline Consent to evacuate & 21,718 & 4 &, $000^{*}$ & ,098 \\
\hline Help - seniors, handicapped & 16,989 & 6 &, $009^{*}$ &, 061 \\
\hline Neighbours - independently & 53,243 & 6 &, $000^{*}$ & ,109 \\
\hline Flood risk map & 46,785 & 6 &, $000^{*}$ & ,102 \\
\hline Official warnings & 44,273 & 8 &, $000^{*}$ & ,101 \\
\hline Potential infections & 15,518 & 8 &, $050^{*}$ &, 059 \\
\hline Water vent & 23,675 & 8 &, $003^{*}$ & ,073 \\
\hline Gas vent & 9,875 & 8 & 274 &, 053 \\
\hline Switch for energy & 16,183 & 6 &, $013^{*}$ &, 061 \\
\hline Handling the water vent & 6,401 & 8 & 602 & ,038 \\
\hline Handling the gas vent & 9,869 & 8 & 274 & 052 \\
\hline Handling the switch for energy & 9,839 & 6 & ,132 &, 048 \\
\hline Information from family members & 4,735 & 3 & ,192 &, 046 \\
\hline Information from neighbours & 14,005 & 3 &, $003^{*}$ &, 080 \\
\hline Information from friends & 27,310 & 3 &, $000^{*}$ &, 111 \\
\hline Information from relatives & 11,564 & 3 &, $009^{*}$ &, 073 \\
\hline Information at school & 9,625 & 3 &, $022^{*}$ &, 066 \\
\hline Information at collage & 57,644 & 3 &, $000^{*}$ &, 162 \\
\hline Information through the informal system & 3,499 & 3 & ,321 &, 040 \\
\hline Information at work & 6,791 & 3 & 079 & 056 \\
\hline Information in religious community & 2,524 & 3 &, 471 &, 034 \\
\hline Information on TV & 5,581 & 3 & ,134 &, 050 \\
\hline Information on radio & 10,475 & 3 &, $015^{*}$ &, 069 \\
\hline Information from the press & 14,285 & 3 &, $003^{*}$ &, 080 \\
\hline Information over the Internet & 41,802 & 3 &, $000^{*}$ &, 138 \\
\hline Trained & 13,973 & 4 &, $007^{*}$ & ,079 \\
\hline Willingness to train & 61,217 & 8 &, $000^{*}$ & ,119 \\
\hline Education through television & 26,046 & 4 &, $000^{*}$ & 138 \\
\hline Education through the radio & 13,973 & 4 &, $007^{*}$ & ,079 \\
\hline Education through the video games & 3,952 & 3 & 267 & ,043 \\
\hline Education through the Internet & 32,511 & 3 &, $000^{*}$ & ,122 \\
\hline Education trough lectures & 45,948 & 3 &, $000^{*}$ & ,145 \\
\hline Informal system & ,678 & 3 & ,878 & ,018 \\
\hline
\end{tabular}

${ }^{*}$ Statistically significant correlation $-p \leq 0.05$ 
Using one-way analysis of variances (one-way ANOVA) it was studied the influence of the incomes of citizens on dependent continuous variables on knowledge for response. Subjects were divided into 4 groups by income level (up to RSD 25,000, up to RSD 50,000, up to 75,000 and over RSD 90,000). Using the homogeneity of variance test it was examined equality of variances in the results for each of the 4 groups. Bearing in mind the results of Levene Statistic, the assumption of homogeneity of variance is not violated in the variable: nearby shelters. For variable in which the assumption is violated, it is presented in table "Robust Tests of Equality of Means" and the results of two tests, Welsh and Brown-Forsythe tests resistant to the violation of the assumption of the equality of variances. For the study purposes, the findings of Welsh test are used.

Based on results, there is a statistically significant difference between the mean values of those groups in the following continuous dependent variables of knowledge: knowledge level $(F=4.17, p=.006$, eta squared $=0.0054-$ small influence); possibility of flooding -1 year $(F=3.11, p=.026$, eta squared $=0.00367-$ small influence); possibility of flooding -5 years $(F=3.944, p=.008$, eta squared $=0.0045-$ small influence); warning systems $(F=13.54, p=0.000$, eta squared $=0.0165-$ small influence $) ;$ police $(F=18.59, p=.000$, eta squared $=0.0218$ - a small effect); first responders $(F=18.241, p=.000$, eta squared $=0.0219$ - small influence); Stuff for emergency situations $(F=21.09, p=.000$, eta squared $=0.0263$ - small influence); evacuation routes $(F=6.907, p=0.000$, eta squared $=0.0091$ - small influence) (Table 6).

Subsequent comparisons using Tukey HSD show that the observed mean value:

- Assessment of food risk of local community in the next 5 years, statistically significantly $(p<0.05)$ and mutually differs among the citizens with household incomes below RSD 25,000 (M = 2.61, SD = 1.435) and citizens with incomes over RSD 90,000 $(M=2.30, S D=1.275)$. Citizens with incomes up to RSD 25,000 to a greater extent, assess flood risk compared to citizens with incomes over RSD 90,000;

- Assessment of food risk of local community in the next 5 years, statistically significantly $(p<0.05)$, and mutually differs among the citizens with household incomes below RSD 75,000 (M = 2.90, SD = 1.317) and citizens with incomes over RSD 90,000 $(M=2.54, S D=1.274)$. Citizens with incomes up to RSD 75,000 to a greater extent, assess flood risk compared to citizens with incomes over RSD 90,000;

- familiarity with warning system in the local community for natural disasters statistically significantly $(p<0.05)$, and mutually differs among the citizens with household incomes up to RSD 25,000 (M = 2.09, SD =1.154) and citizens with incomes up to $\operatorname{RSD} 75,000$ ( $M=2.53, S D=1.127$ ). Citizens with incomes up to RSD 25,000 to a lesser extent, assess flood risk compared to citizens with income up to RSD 75,000;

- familiarity with police jurisdiction statistically significantly $(p<0.05)$, and mutually differs among the citizens with household incomes below RSD 25,000 $(M=2.46, S D=1.276)$ and citizens with incomes below RSD $75,000(M=2.95, S D=1.132)$. Citizens with incomes up to RSD 25,000 to a lesser extent are familiar with police jurisdiction compared to citizens with incomes up to RSD 75,000;

- familiarity with competencies of first responders statistically significantly $(p<0.05)$, and mutually differs among the citizens with household incomes up to RSD 25,000 ( $M=2.57$, $S D=1.290)$ and citizens with incomes up to RSD 75,000 $(M=3.10, S D=1.176)$. Citizens with incomes up to RSD 25,000 to a lesser extent are familiar with jurisdiction of first responders compared to citizens with incomes over RSD 90,000; 
- familiarity with competencies of stuff for emergency situations statistically significantly $(p<0.05)$, and mutually differs among the citizens with household incomes up to RSD $25,000(M=2.40, S D=1.227$ ) and citizens with incomes up to RSD 75,000 $(M=2.97, S D=1.236)$. Citizens with incomes up to RSD 25.000 to a lesser extent are familiar jurisdiction of stuff for emergency situations compared to the citizens with incomes up to RSD 75,000;

- familiarity with evacuation routes statistically significantly $(p<0.05)$ and mutually differs among the citizens with household incomes below RSD 25,000 ( $M=2.27, S D=1.269)$ and citizens with incomes below RSD 75,000 ( $M=2,59, S D=1.415)$. Citizens with incomes up to RSD 25,000 to a lesser extent know the routes for evacuation compared to citizens with incomes up to RSD 75,000;

- familiarity with risk assessment and plan of protection and rescue from the consequences of floods statistically significantly $(p<0.05)$, and mutually differs among the citizens with household incomes below RSD 25,000 $(M=2.27, S D=1.201)$ and citizens with incomes up to RSD 75,000 $(M=3.02, S D=1.179)$. Citizens with incomes up to RSD 25,000 to a lesser extent are familiar with risk assessment and plans for protection and rescue compared to citizens with incomes up to RSD 75,000.

Table 6 - Results of one-way ANOVA of different groups of income levels and continuous dependent variables of knowledge for response

\begin{tabular}{|l|c|c|c|c|}
\hline \multicolumn{4}{|c|}{ Test homogenosti varijanse } \\
\hline & Levene Statistic & df1 & df2 & \multicolumn{1}{l|}{ Sig. } \\
\hline Knowledge level & 8,936 & 3 & 2219 &, 000 \\
\hline Possibility of flooding - 1 year & 6,754 & 3 & 2306 &, 000 \\
\hline Possibility of flooding - 5 years & 6,992 & 3 & 2261 &, 000 \\
\hline Warning systems & 4,160 & 3 & 2271 &, 006 \\
\hline Police & 13,102 & 3 & 2278 &, 000 \\
\hline Fire depatment & 7,895 & 3 & 2274 &, 000 \\
\hline Headquarters for emergency situations & 4,864 & 3 & 2275 &, 002 \\
\hline Evacuation routes & 4,160 & 3 & 2270 &, 006 \\
\hline Nearby shelters & $\mathbf{1 , 9 4 0}$ & $\mathbf{3}$ & $\mathbf{2 2 7 4}$ &, $\mathbf{1 2 1 ^ { * }}$ \\
\hline Assessment of vulnerability and plans & 5,420 & 3 & 2266 &, 001 \\
\hline
\end{tabular}

* the assumption of the equality of variance is not broken - Sig. > 0.05

\begin{tabular}{|l|l|c|c|c|c|c|}
\hline \multicolumn{9}{|c|}{ ANOVA } \\
\hline \multicolumn{3}{|c|}{$\begin{array}{c}\text { Sum of } \\
\text { Squares }\end{array}$} & df & $\begin{array}{c}\text { Mean } \\
\text { Square }\end{array}$ & F & Sig. \\
\hline \multirow{3}{*}{ Knowledge level } & Between Groups & 12,360 & 3 & 4,120 & 4,033 &, 007 \\
\cline { 2 - 9 } & Within Groups & 2266,972 & 2219 & 1,022 & & \\
\hline & Total & 2279,332 & 2222 & & & \\
\hline \multirow{3}{*}{ Possibility of flooding - 1 year } & Between Groups & 15,567 & 3 & 5,189 & 2,832 &, 037 \\
\cline { 2 - 9 } & Within Groups & 4224,989 & 2306 & 1,832 & & \\
\cline { 2 - 9 } & Total & 4240,556 & 2309 & & & \\
\hline \multirow{3}{*}{ Possibility of flooding - 5 years } & Between Groups & 19,517 & 3 & 6,506 & 3,415 &, 017 \\
\cline { 2 - 9 } & Within Groups & 4307,837 & 2261 & 1,905 & & \\
\cline { 2 - 8 } & Total & 4327,354 & 2264 & & & \\
\hline
\end{tabular}


VOJNO DELO, 4/2016

\begin{tabular}{|c|c|c|c|c|c|c|}
\hline \multicolumn{7}{|c|}{ ANOVA } \\
\hline & & $\begin{array}{l}\text { Sum of } \\
\text { Squares }\end{array}$ & df & $\begin{array}{c}\text { Mean } \\
\text { Square }\end{array}$ & $\mathrm{F}$ & Sig. \\
\hline \multirow{3}{*}{ Warning systems } & Between Groups & 52,633 & 3 & 17,544 & 12,704 &, 000 \\
\hline & Within Groups & 3136,179 & 2271 & 1,381 & & \\
\hline & Total & 3188,811 & 2274 & & & \\
\hline \multirow{3}{*}{ Police } & Between Groups & 77,238 & 3 & 25,746 & 16,928 &, 000 \\
\hline & \begin{tabular}{|l|} 
Within Groups \\
\end{tabular} & 3464,602 & 2278 & 1,521 & & \\
\hline & Total & 3541,840 & 2281 & & & \\
\hline \multirow{3}{*}{ Fire depatment } & Between Groups & 81,428 & 3 & 27,143 & 16,991 &, 000 \\
\hline & Within Groups & 3632,732 & 2274 & 1,598 & & \\
\hline & Total & 3714,160 & 2277 & & & \\
\hline \multirow{3}{*}{$\begin{array}{l}\text { Headquarters for emergency } \\
\text { situations }\end{array}$} & Between Groups & 96,213 & 3 & 32,071 & 20,510 & ,000 \\
\hline & Within Groups & 3557,304 & 2275 & 1,564 & & \\
\hline & Total & 3653,517 & 2278 & & & \\
\hline \multirow{3}{*}{ Evacuation routes } & Between Groups & 33,657 & 3 & 11,219 & 7,026 &, 000 \\
\hline & Within Groups & 3624,721 & 2270 & 1,597 & & \\
\hline & \begin{tabular}{|l|} 
Total \\
\end{tabular} & 3658,378 & 2273 & & & \\
\hline \multirow{3}{*}{ Nearby shelters } & Between Groups & 7,844 & 3 & 2,615 & 1,727 & ,159 \\
\hline & Within Groups & 3442,094 & 2274 & 1,514 & & \\
\hline & Total & 3449,939 & 2277 & & & \\
\hline \multirow{3}{*}{$\begin{array}{l}\text { Assessment of vulnerability and } \\
\text { plans }\end{array}$} & Between Groups & 11,565 & 3 & 3,855 & 2,748 & ,041 \\
\hline & Within Groups & 3179,026 & 2266 & 1,403 & & \\
\hline & Total & 3190,591 & 2269 & & & \\
\hline
\end{tabular}

* there is a statistically significant difference between the mean values of the dependent variables in 4 groups - Sig. $\leq 0.05$

\begin{tabular}{|l|l|l|l|l|l|}
\hline \multicolumn{9}{|c|}{ Robust Testss of Equality of Means } & Statistic & df1 & df2 & Sig. \\
\hline \multirow{2}{*}{ Knowledge level } & Welch & $\mathbf{4 , 1 7 9}$ & $\mathbf{3}$ & $\mathbf{6 9 3 , 1 0 7}$ &, $\mathbf{0 0 6} \mathbf{6}^{*}$ \\
\cline { 2 - 6 } & Brown - Forsythe & $\mathbf{4 , 1 1 7}$ & $\mathbf{3}$ & $\mathbf{1 2 6 6 , 5 0 5}$ & $\mathbf{, 0 0 6}^{*}$ \\
\hline \multirow{2}{*}{ Possibility of flooding - 1 year } & Welch & 3,114 & 3 & 730,759 &, $026^{*}$ \\
\cline { 2 - 6 } & Brown - Forsythe & 2,950 & 3 & 1419,323 &, $032^{*}$ \\
\hline \multirow{5}{*}{ Possibility of flooding - 5 years } & Welch & 3,944 & 3 & 712,441 &, $008^{*}$ \\
\cline { 2 - 6 } & Brown - Forsythe & 3,566 & 3 & 1422,737 &, $014^{*}$ \\
\hline \multirow{3}{*}{ Warning systems } & Welch & 13,540 & 3 & 702,388 &, $000^{*}$ \\
\cline { 2 - 6 } & Brown - Forsythe & 12,118 & 3 & 1067,220 &, $000^{*}$ \\
\hline \multirow{5}{*}{ Police } & Welch & 18,596 & 3 & 718,398 &, $000^{*}$ \\
\cline { 2 - 6 } & Brown - Forsythe & 17,268 & 3 & 1281,083 &, $000^{*}$ \\
\hline \multirow{4}{*}{ Fire depatment } & Welch & 18,241 & 3 & 716,313 &, $000^{*}$ \\
\cline { 2 - 6 } & Brown - Forsythe & 17,209 & 3 & 1260,135 &, $000^{*}$ \\
\hline & Welch & 21,097 & 3 & 717,336 &, $000^{*}$ \\
\cline { 2 - 6 } & Brown - Forsythe & 20,847 & 3 & 1316,667 &, $000^{*}$ \\
\hline a. Asymptotically F distributed. & Welch & 6,907 & 3 & 699,922 &, $000^{*}$ \\
\cline { 2 - 6 } & Brown - Forsythe & 6,631 & 3 & 1062,914 &, $000^{*}$ \\
\cline { 2 - 6 } & Welch & 2,693 & 3 & 691,444 &, $045^{*}$ \\
\cline { 2 - 6 } & Brown - Forsythe & 2,534 & 3 & 1026,059 &, 056 \\
\hline
\end{tabular}

* there is a statistically significant difference between the mean values of the dependent variables in 4 groups - Sig. $\leq 0.05$ 


\section{Relationship between income levels and possession of supplies and plans}

The results of Chi-square test of independence $\left(x^{2}\right)$ showed a statistically significant relationship between income level and the following variables on supplies and plans: supplies at home $(p=0.020<0.05, v=0,063$ - small influence); food supply $(p=0.031<0.05$, $v=0.099$ - small influence); water supply $(p=0.027<0.05, v=0.104$ - small influence); radio-transistor $(p=0.000<0.05, v=0,145$ - small influence); flashlight $(p=0.020<0.05$, $v=0.091$ - small influence); shovel $(p=0.021<0.05, v=0.091$ - small influence); hack $(p=$ $0.021<0.05, v=0.091$ - small influence); hoe and spade $(p=0.006<0.05, v=0.143$ - small influence); apparatus for firefighting ( $p=0.002<0.05, v=0.116$ - small influence); restocking $(p=0.005<0.05, v=0,087$ - small influence); supplies in the car $(p=0.000<0.05$, $v=0.074$ - small influence); first aid kit in the home $(p=0.000<0.05, v=0,087$ - small influence); first aid kit in the vehicle ( $p=0.000<0.05, v=0.128$ - small influence); first aid kit easily accessible ( $p=0.000<0.05, v=0.084$ - small influence); discussion on the plan ( $p=<0.05, v=0$, - small influence); copies of documents $(p=0.01<0.05, v=0,063$ - small influence). On the other hand, there was no statistically significant relationship with variables: plan for response $(p=0.207>0.05)$; and insurance $(p=0.088>0.05)$ (Table 7$)$.

Based on results, in the highest percentage:

- Citizens with household incomes over RSD 90,000, have supplies (36\%), food supplies for four days $(68.5 \%)$, water supply for four days $(52 \%)$, radio-transistor (33.3\%), flashlight $(50.5 \%)$, shovel $(54.8 \%)$, hack $(39.8 \%)$, hoe $(54.4 \%)$, apparatus for firefighting $(11.3 \%)$, supplies in the car $(7,3 \%)$, first aid kit at home $(70.6 \%)$, in the vehicle $(41 \%)$, first aid kit in an easily accessible place $(73.1 \%)$, discussion on plan for response with household members $(25.9 \%)$, once a month $(44 \%)$, once a year $(26.6 \%)$ replenish supplies, keep copies of important personal, financial and insurance documents in a safe place $(33.8 \%)$, have a water supply for two days (24\%);

- Citizens with household incomes up to RSD 75,000 have food supplies for two days $(21.7 \%)$, water supplies for one day $(11.9 \%)$, have water supplies for two days $(37.3 \%)$;

- Citizens with household incomes up to RSD 50,000 have never replenished supplies (50.6\%);

- Citizens household incomes up to RSD 25,000 have food supplies for one day $(19.8 \%)$, water supplies for one day $(25.4 \%)$.

On the other hand, in the smallest percentage:

- Citizens with household incomes up to RSD 75,000 have supplies (22.9\%), food supplies for one day (12,3,8\%), one a month $(26.7 \%)$ and have never $(50.6 \%)$ replenished kept supplies;

- Citizens with household incomes up to RSD 25,000 have food supplies for two days $(13.2 \%)$ to water supplies for four days $(40.7 \%)$, have a radio-transistor $(15.9 \%)$ and flashlight (36.1\%), hack (23.5\%), apparatus for firefighting $(27.3 \%)$, first aid kit at home $(47.5 \%)$, first aid kit in the vehicle (38\%), first aid kit in an easily accessible place $(21 \%)$, discussion on plan for response to with household members (13.6\%), keep copies of important personal, financial and insurance documents in a safe place $(33.8 \%)$;

- Citizens with household incomes up to RSD 50,000 have supplies for four days (57\%); have a shovel (38.4\%), hoe (29.8\%) and supplies in the car $(4.8 \%)$. 
VOJNO DELO, 4/2016

Table 7 - Results of Chi-square test of independence ( $\chi 2$ ) of income levels and having supplies and response plans

\begin{tabular}{|c|c|c|c|c|}
\hline Kategorijske promenljive & value & df & Asymp. Sig. $(2$ - sided $)$ & Cramers v \\
\hline Supplies at home & 18,160 & 8 & ,020* &, 063 \\
\hline Food supplies & 13,859 & 6 &, $031^{*}$ & 099 \\
\hline Water supplies & 14,239 & 6 &, $027^{*}$ & ,104 \\
\hline Radio-transistor & 24,064 & 3 &, $000^{*}$ & ,145 \\
\hline Flashlight & 9,848 & 3 &, $020^{*}$ & 091 \\
\hline Shovel & 9,746 & 3 &, $021^{*}$ & 091 \\
\hline Hack & 12,508 & 3 &, $006^{*}$ & ,103 \\
\hline Hoe and spade & 24,098 & 3 &, $000^{*}$ & ,143 \\
\hline Apparatus for fire-fighting & 14,828 & 3 &, $002^{\star}$ & ,116 \\
\hline Restocking & 18,468 & 6 &, $005^{\star}$ & 087 \\
\hline Supplies in car & 35,083 & 9 &, $000^{*}$ &, 074 \\
\hline First aid kit at home & 32,712 & 6 &, $000^{*}$ & 087 \\
\hline First aid kit in vehicle & 57,862 & 6 &, $000^{*}$ & ,128 \\
\hline First aid kit - easily accessible & 27,022 & 6 &, $000^{*}$ & ,084 \\
\hline Response plan & 15,665 & 12 & ,207 &, 048 \\
\hline Discussion of the plan & 22,176 & 6 &, $001^{*}$ & 072 \\
\hline Copies of documents & 16,727 & 6 &, $010^{*}$ & 063 \\
\hline Insurance & 11.027 & 6 & 088 & 050 \\
\hline
\end{tabular}

* Statistically significant correlation - $p \leq 0.05$

\section{Conclusion with recommendations}

Citizens with household incomes over RSD 90,000, in a higher percentage/greater extent: take preventive measures, would give money to help victims affected by floods, water level rise makes them to think on preparedness, have recently started to prepare and preparations have last at least 6 months, they know what flood is and know safety procedures, they point out that someone at school talked them about floods, they know what help is needed by elders, disabled and infants during floods, they would evacuate to a friend's place during floods, stand out that their neighbors can self-rescue in the event of a flood, they know what to do after an official warning about the approach of floods, say that they are familiar with viruses and infections that accompany period after the flood, they know where water valve is, switch for electricity; point out that they received information on floods over the Internet, they passed a certain training in the field of natural disasters, they would like to be educated about natural disasters caused by floods over the radio, the Internet, an informal education system; have supplies, food supplies for four days, water supplies for four days, radio-transistor, flashlight, shovel, hack, hoe, apparatus for fire firefighting, supplies in the car, first aid kit at home, in the car, first aid kit in an easily accessible place, they discussed the plan for response with household members, once a month, once a year, replenish kept supplies, keep copies of important personal, financial and insurance documents in a safe place, have supplies of water for two days;

- Citizens with household incomes up to RSD 75,000 emphasize that someone at work talked them about floods, they know where live elders, disabled, infants, would be 
evacuated during floods, received flood information from relatives, at school, at university, on the radio, and in the press, have food supplies for two days, water supplies for one day, have water supplies for two days, have food supplies for one day, once a month and never replenish supplies;

- Citizens with household incomes up to RSD 50,000 would engage in providing assistance to victims in the field, would be evacuated to the upper floors of the house, evacuated to the upper floors of the house during floods; evacuated to the rented apartments during floods, they say that they are familiar with flood risk map in the local community, point out that they received information on floods from neighbors, friends;

- Citizens with household incomes up to RSD 25,000 are still not prepared, but intend to take measures in the next 6 months, are still not prepared, but will start preparing next month, would evacuated to neighbors' places during floods, would evacuated to neighbors' places and to shelters during floods; they would like to go through some training in the field of natural disasters, and they would like to be educated about natural disasters caused by floods on television,

When it comes to incomes at the household level, the results suggest that in the lowest percentage:

- Citizens with household incomes over RSD 90,000 would be evacuated to neighbors' places and to rented apartments, they know where water valve is, point out that they got information on floods from neighbors, they would like to be educated about natural disasters caused by floods on television, through radio, Internet, informal education,

- Citizens with household incomes up to RSD 75,000 know what flood means and are familiar with security response procedures, would be evacuated to the upper floors of the house during the flood; would evacuated to shelters, they point out that their neighbors can self-rescue in the event of a flood, they know what to do after an official warning about the approach of the flood, they know where the switch for electricity is located $(77.6 \%)$;

- Citizens with household incomes up to RSD 50,000 point out that somebody at school talked them about floods, are familiar with viruses and infections that accompany period after the floods (42.9\%); point out that they have been given training in the field of natural disasters $(4.1 \%)$;

- Citizens with household incomes up to RSD 25,000 would be evacuated to a friend's place during the flood, they point out that someone at work talked them about the floods, they know where live elders, disabled and infants, they know what help is needed by elders, disabled and infants during the floods, are familiar with flood risk map in the local community, point out that they got information on floods from neighbors, relatives, at faculty, over the radio, in the press, over the Internet.

- Citizens with household incomes up to RSD 25,000 took preventive measures, would give money to help victims affected by floods, would be engaged in providing assistance to victims in the field, water level rise makes them to think on preparedness, carried out preparations for at least 6 months, supplies for two days, water supplies for four days, radio-transistor, flashlight, hack, apparatus for firefighting, first aid kit in the home, first aid kit in the vehicle, keep a first aid kit in an easily accessible place, discussion on plans for response with household members, keep copies of important personal, financial and insurance documents in a safe place. 
Furthermore, citizens with incomes up to RSD 50,000 scored a higher level of preparedness of the state, of the local community for response to floods compared to citizens with incomes up to RSD 25,000; people with incomes over RSD 90,000 scored a higher level of assessments of confidence in their own abilities and the importance of taking preventive measures for response to floods compared to citizens with incomes up to RSD 25,000; people with incomes up to RSD 25,000 to a greater extent agree with statement "I think first responders will help me, so I do not need such measures", "I have no time for that", "It is very expensive", "I can not prevent it", as a reason compared to citizens with incomes up to RSD 75,000; people with incomes up to RSD 25,000 to a greater extent expect help from family, non-governmental humanitarian organizations, international humanitarian organizations, religious communities, first responders compared to the citizens with incomes over RSD 90,000; people with incomes up to RSD 25,000 to a greater extent, expect help from the neighbors compared to citizens with incomes over RSD 90,000; people with incomes up to RSD 25,000 to a greater extent, expect assistance from police, emergency medical service, military, compared to citizens with incomes up to RSD 75,000; people with incomes up to RSD 25,000 to a lesser extent, assess the efficiency of the army, emergency medical service and staffs of emergency situations compared to the citizens with incomes over RSD 90,000; people with incomes up to RSD 25,000 to a lesser extent, assess efficiency compared to the citizens with incomes over RSD 90,000.

\section{Recommendations for improving preparedness of citizens}

It should influence on citizens who have incomes up to RSD 25,000: to take measures of preparedness to respond, to deposit funds to help people threatened by floods, to get engaged in assisting flood victims in the field, to take measures of preparedness encouraged by displaying images or recordings of raising water, to raise the level of confidence in their own abilities by additional education or specific training. They should be informed about the competencies of the police, first responders and staff for emergency situations during natural disasters caused by floods. They need to be informed about the evacuation routes and nearby shelters. They should be encouraged to acquire food supplies for two days, flashlight, hack, apparatus for fire fighting, first aid kit and to discuss on how to react. Citizens with incomes up to RSD 90,000 should be influenced to evacuate in emergency situations to neighbors' places and rented apartments if needed. They should be educated about where water valve is located. Education has to be made through the radio, the internet, and non-formal education system. Citizens with household incomes up to RSD 75,000 should be influenced primarily through education about what flooding is and how to react in such situations. They should be encouraged to be educated about what they should do after official warnings about the approach of the flood and where switch for electricity is located. Citizens with incomes up to RSD 50,000 need to be learned about viruses and infections that accompany the period after floods and encouraged to undergo specific training in handling such situations. Citizens with incomes up to RSD 75,000 should be encouraged to acquire food supplies at least for one day, and to replenish them once a month. 


\section{References}

[1] Baker, E. J. (2011). Household preparedness for the aftermath of hurricanes in Florida. Applied Geography, 31(1), 46-52.

[2] Council for Excellence in Government (CEG) (2006). Introducing the Public Readiness Index: A survey - based tool to measure the preparedness of individuals, families and communities. Washington, DC: CEG.

[3] Cohen, J.W., Statistical power analysis for the behavioral sciences (2nd edn). (1988). Hillsdale, NJ: Lawrence Erlbaum Associates.

[4] Cvetković, V. (2015). Fenomenologija prirodnih katastrofa - teorijsko određenje i klasifikacija prirodnih katastrofa. Bezbjednost, policija i građani, 3 - 4, 311-335.

[5] Cvetković, V. (2015). Spremnost građana za reagovanje na prirodnu katastrofu izazvanu poplavom u Republici Srbiji. (Doktorska disertacija), Univerzitet u Beogradu, Fakultet bezbednosti.

[6] Cvetković, V. (2015). Spremnost za reagovanje na prirodnu katastrofu - pregled literature. Bezbjednost, policija i građani, 1-2/15(XI), 165-183.

[7] Cvetković, V., Gačić, J., \& Jakovljević, V. (2015). Uticaj statusa regulisane vojne obaveze na spremnost građana za reagovanje na prirodnu katastrofu izazvanu poplavom u Republici Srbiji. Ecologica, 22(80), 584-590. Survey.

[8] FEMA (2009). Personal Preparedness in America: Findings from the Citizen Corps National

[9] Gillespie, D. F., \& Streeter, C. L. (1987). Conceptualizating and measuring disaster preparedness. International Journal of Mass Emergencies and Disasters, 5(2), 155-176.

[10] Ostojić, G. D. (2014). Environmental refugees: Direct or indirect way to a conflict. Vojno delo, 66(1), 51-83.

[11] Tierney, K. J., Lindell, M. K., \& Perry, R. W. (2002). Facing the unexpected: disaster preparedness and response in the United States. Disaster Prevention and Management: An International Journal, 11(3), 222-222.

[1] Vratuša-Žunjić, V. A. (2001). Natural disasters and the'meteorological warfare. Vojno delo, 53(4-5), 85-91. 